\title{
Construction of Language Teachers' Professional Competence in Education for Sustainable Development in Higher Education for Post-pandemic Era
}

\author{
Yan Liu \\ Yuncheng University, Yuncheng, China \\ Wenjin Qi \\ Yuncheng University, Yuncheng, China
}

\begin{abstract}
Education for sustainable development is essentially a value education. It is an educational process that aims at the value recognition, perception, practice and sustainable value tendency of sustainable development. Language teachers' competences for sustainable development education is a professional ability manifested in sustainable development education activities based on their recognition of relevant concepts and willingness to practice sustainable values in their personal lives and educational activities in higher education. The connotation, pedagogic goals and characteristics of sustainability education constitute the foundation of language teachers' professional competences in education for sustainable development, which fall into three major categories of professional knowledge, professional skills and professional attitude.
\end{abstract}

Index Terms - professional competence, education for sustainable development, higher education, professional development, language teacher, post-pandemic era

\section{INTRODUCTION}

Covid-19 pandemic has been a global disaster in many ways (Gao \& Zhang, 2020). It is a consequence of nature due to unsustainable development of human activities. The pandemic outbreak has set people to rethink the relationships between humans and nature. It has brought the issue of sustainable development in terms of environmental, social and economic dimensions back to the top priority in human development. Since education plays a role of a core discipline to disseminate sustainable development principles, increasing emphasis and attention are devoted to the education for sustainable development (Michalos et al., 2012; Tilbury, 2011; Olsson et al., 2015).

In the 21st century, the theme of overall development for human society lies in sustainable development, which is pursued by the world as a value goal. And the Sustainable Development Goals have become a mainstream aim since the United Nations Sustainable Development Summit in September 2015 adopted the document Transforming Our World: the 2030 Agenda for Sustainable Development. The World Education Forum in 2015 planned a global education roadmap for 2030 and put forward specific ideas and requirements for promoting education for sustainable development (ESD). Subsequently, the Global Action Plan for Education for Sustainable Development was launched, and the concepts of sustainable development and education for sustainable development thus gained global recognition and attention.

In particular, China has put forward higher requirements for the construction of ecological civilization and the goal of "greening" the country's construction. In 2016, China released the "China National Program for the Implementation of the 2030 Agenda for Sustainable Development", which fully launched the implementation of the 2030 Agenda for Sustainable Development. In 2017, a speech, entitled "Building a Community with a Shared Future for Mankind", was delivered by President Xi of China, advocating a green, low-carbon, circular, sustainable production and lifestyle to balance the advancement of sustainable development (Xi, 2017). It clarifies China's national position in the '2030 Sustainable Development Agenda'.

Education is a powerful guarantee for implementing sustainable development. Irina Bokova, the former Director-General of UNESCO, emphasized that education must teach people how to learn coexisting on a stressful planet. It must value cultural literacy, and help integrate the social, economic and environmental aspects of sustainable development (UN, 2015). In other words, education for sustainable development is the key to achieving sustainability. As an educational activity, the participation of language teachers with sustainable development educational capabilities is indispensable in the process of promoting ESD.

However, a major challenge has emerged as there is a clear mismatch between the essential significance and responsibilities of ESD and the existing qualified language teachers who are able to carry out ESD. And teacher training 
is an effective way to bridge the gap. Therefore, from the standpoint of language teacher trainers, this paper intends to establish the structure of language teachers' professional competences in the context of ESD for the purpose of providing guidance and reference for pertinent teacher training.

\section{LITERATURE REVIEW}

Education for sustainable development has been encountering multiple and complex social, economic, cultural, and environmental problems and issues. It highlights the combination of educational theories and social practice, as well as focuses on participation in solving practical problems associated with sustainable development. Accordingly, language teachers are expected to develop their professional competence to promote sustainable development in higher education.

\section{A. ESD Definition}

There are multiple versions of definitions for ESD. The core idea lies in the process of preparing students with knowledge, skills, and attributes in order to work and live in such a way that it ensures their environmental, social and economic well-being both at present and for future (Longhurst, 2014). To be specific, it contextualizes their learning to the realities of their specialization, personal and study life in the way of motivating them to develop a notion of global citizenship, social justice, environmental and ecological protection, and sustainable economic development (Longhurst, 2014).

Centered on sustainable values, education for sustainable development emerged upon the needs of new era of sustainable development (Zhang, 2019). It also teaches people new knowledge and skills to enable them to respond to current and common challenges facing human society in the future. And it is considered as a holistic approach for implementing a dynamic and transformative process to further promote the sustainable development of society, economy, environment and culture in educational institutions (Biasutti, 2017).

Universities take it as their primary responsibility and obligation to contribute to a sustainable society in the perspectives of increasing teachers' professional competence in ESD and leading to a deeper understanding and appreciation of this concept as well as larger-scale of implementation in the higher education (Barth \& Rieckmann, 2012).

\section{B. Aim}

The aim of ESD consists of two dimensions: one is for teaching, and the other one is for learning. ESD practice in higher education intends to promote and strengthen students' skills to develop a more sustainable social contest (Filho, 2015). The application of ESD in higher education could upgrade university language teachers in terms of professional development in the context of sustainable development as well as cultivate global citizens with sustainability values, knowledge and skills (Biasutti, 2017). The essence of teaching falls on the commitment to connect students' academic learning with meaningful and consistent experience in a number of educational settings. Pedagogical methods and approaches are conducted to deliver experiential learning and develop key skills such as critical thinking skills, problem-solving skills, and creativity.

On the other hand, students are taught in such a way that it is more than just dissemination of information but a value system and attitudes towards life that are embedded throughout university life. Their concept of sustainability is established and reinforced through the participation of community workshops or projects. Skills that are needed for personal and professional development, such as communication, collaboration and innovation, are demonstrated and transferred to students. It is evidenced to exert a significant impact on their future employability as they continue to develop their understanding and behaviors of sustainable development.

Zhang (2019) has summarized and listed the ultimate goals of ESD as follows: Education at all levels should help educate people to (1) Establish sustainable development values; (2) Learn scientific knowledge of sustainable development; (3) Cultivate sustainable learning ability; (4) Practice sustainable lifestyle; (5) Pay attention to and participate in solving practical problems of sustainable development.

\section{Features}

It calls for a shift in people's mind set towards more sustainable values, behaviors and lifestyles for a better quality of human life (Besong \& Holldan, 2015). Similarly, an educational refocus should be placed on developing and transferring competences in sustainable development. It is pointed out that a major characteristic of ESD is its interdisciplinary nature as it reflects complex issues across various dimensions of the surroundings.

A departure from courses focused on mere knowledge transmission is proposed, and at the same time, an emphasis on the development of autonomous learning and competences is encouraged in higher education institutions. ESD provides a new pedagogical perspective with its interdisciplinarity and student-centered approaches for higher education (Natkin \& Kolbe, 2016). It also encourages future-oriented skills and critical thinking (Biasutti \& Frate, 2017). In response, universities should integrate sustainability into their curricula design and support collaborative teaching and research projects involved with sustainable development as an integrated part of the institution's utmost mission, which could be viewed as a catalyst for systemic institutional change and educational reform (Wals et al., 2014).

Meanwhile, the introduction of ESD practice in higher education could be regarded as an impetus for promoting 
professional competence of academic language teachers in the sustainability education context. As teachers are an essential pillar in training millions of graduates across all disciplines each year, and they are in a strategic position to foster sustainable awareness, there is no doubt that teachers' capability and teacher education are critical to achieving ESD (Biasutti et al., 2017).

\section{STRUCTURE OF PROFESSIONAL COMPETENCE IN ESD}

A systematic literature review was used to capture and analyse literature that dealt with the content of professional competence in ESD. Existing and emergent structures related to language teachers' ESD competence were identified and examined. This paper selects two representative models from macro and micro perspectives respectively.

\section{A. Macro Professional Development Model of ESD}

Biasutti et al. (2017) put forward a comprehensive macroscopic framework for teachers' professional development in ESD in higher education.

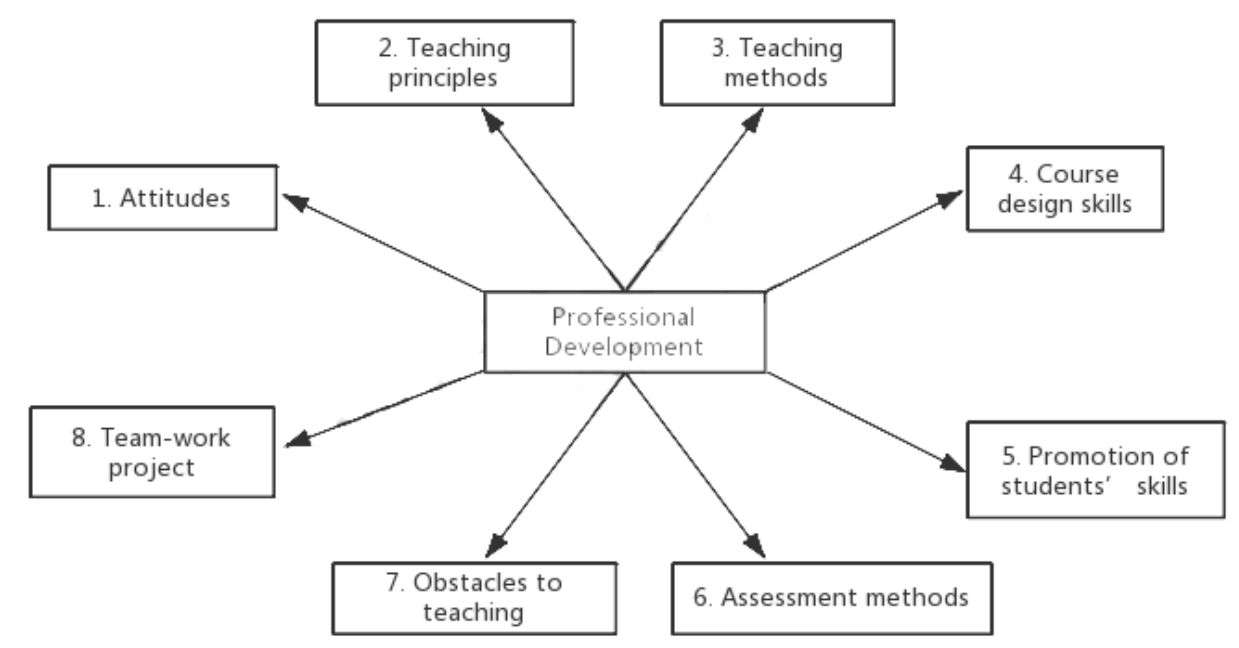

Figure 1. Framework for teachers' professional development in ESD in higher education.

As shown in the above figure, teachers' professional development consists of eight categories, covering three levels of teaches' life. They are personal level, professional level and interpersonal level (Biasutti et al., 2017). It also applies to the professional development of language teachers in higher education, illustrated as following:

(1)Attitudes. It refers to language teachers' awareness, beliefs and attitudes towards ESD. It includes language teachers' obligation and responsibility as an educator to promote sustainable development principles. It further covers their thoughts and reflections upon the impact of sustainability in working and personal life.

(2)Teaching principles. It refers to the methodological and theoretical principles that language teachers have applied to their teaching practices under the framework of sustainability concepts and the integration of alternative educational methods, such as learner-centred approach, linking theory with practice, and interactions with external agencies and communities.

(3)Teaching methods. According to ESD principles, language teachers should endeavour to modify their teaching methods and techniques for more extensive involvement by students, who would benefit more from the autonomous learning process and an active role in classroom activities.

(4)Course design skills. It refers to the comprehensive ability to design, modify and implement the syllabus, including outlining teaching and learning objectives, selecting teaching materials and didactic approaches, measuring students' cognitive load and shaping their time management skills.

(5)Promotion of students' skills. It aims to cultivate and enhance students' capabilities. In specific, it is important for teachers to recognize the significance of broadening students' individual interests in cultural study and raising their sustainability awareness in their life. Additionally, language teachers should also be obliged to address other skills such as life-long learning skills, critical-thinking and problem-solving skills.

(6)Assessment methods. It is suggested that language teachers adopt new assessment process of multiple techniques to evaluate students. In accordance with pedagogic objectives, teaching outcomes should be evaluated and assessed in various forms such as portfolios, reflection paper, reports, individual presentations, group discussions, project-based teamwork, and so on. 
(7)Difficulties and obstacles. It firstly originates from students' resistance to the changes induced by ESD reform. Other issues pertain to class management, teaching time management, teachers' substantial workload and so on.

(8)Team-work project. It touches upon aspects of characterizing group activities during the teaching practice. It highlights the importance of disseminating the sustainable development ideas and ESD principles through collaborative learning.

\section{B. Micro Overview of Teachers' Professional Competence in ESD}

In contrast with Biosutti's (2017) framework, after collecting and combing previous literature, Zhang (2019) established a holistic overview of the connotation and denotation of ESD language teachers' competence. He put their professional competence in ESD into three dimensions, namely professional values, professional knowledge, and professional skills, as shown in the following tables.

1. Professional value

Zhang (2019) developed the content of professional values of ESD from 11 indicators in three categories: values of sustainable development, affects, and educational concepts.

TABLE I.

TEACHERS' PROFESSIONAL VALUE OF ESD

\begin{tabular}{|c|c|c|}
\hline Category & Sub-category & Indicators \\
\hline \multirow[t]{5}{*}{$\begin{array}{l}\text { Values of } \\
\text { sustainable } \\
\text { development }\end{array}$} & $\begin{array}{l}\text { Understanding of the } \\
\text { significance of sustainable } \\
\text { development and ESD }\end{array}$ & $\begin{array}{l}\text { Fully aware of the facts that: } \\
\text { Human beings and the environment are interdependent and share a } \\
\text { common destiny; } \\
\text { Sustainable development is the ultimate goal for human beings; } \\
\text { Human economic and social development cannot exceed the carrying } \\
\text { capacity of resources and the environment; } \\
\text { ESD equips educators with knowledge, skills and values to promote the } \\
\text { realization of sustainability; } \\
\text { ESD is interdisciplinary by nature and could be integrated in different } \\
\text { disciplines. }\end{array}$ \\
\hline & Environmental values & $\begin{array}{l}\text { Recognize the facts that: } \\
\text { Human being is an integral part of the natural environment; } \\
\text { Human should respect the rights of other living things on the planet; } \\
\text { Human should take actions to protect the natural environment and natural } \\
\text { resources. }\end{array}$ \\
\hline & Social values & $\begin{array}{l}\text { Fully aware of the facts that: } \\
\text { Everyone is free and equal; } \\
\text { Value life and respect the basic rights of others; } \\
\text { Recognize the significance of a peaceful and non-violent world to humanity. }\end{array}$ \\
\hline & Cultural values & $\begin{array}{l}\text { Appreciate the diversity of world cultures; } \\
\text { Understand and respect the differences between various cultures; } \\
\text { Value national culture and tradition. }\end{array}$ \\
\hline & Resources values & $\begin{array}{l}\text { Acknowledge the circular economy as a sustainable economic } \\
\text { development model; } \\
\text { Develop a resource-conservation lifestyle. }\end{array}$ \\
\hline \multirow[t]{4}{*}{ Affects } & Responsibility awareness & $\begin{array}{l}\text { Role model in protecting natural environment and natural resources in life } \\
\text { and work; } \\
\text { Willingness of involving in environmental volunteer activities. }\end{array}$ \\
\hline & Sustainability obligation & $\begin{array}{l}\text { Obligation in teaching sustainability in schools; } \\
\text { Willingness to spread sustainable concepts and ideas to people around. }\end{array}$ \\
\hline & Passion for ESD & $\begin{array}{l}\text { Continuous interest in sustainability issues; } \\
\text { Active acquiring relevant knowledge; } \\
\text { Active participation in further ESD trainings. }\end{array}$ \\
\hline & Sustainable lifestyle & $\begin{array}{l}\text { Actively advocate and practice water and electricity saving and } \\
\text { low-carbon travel in daily life; } \\
\text { Environmentally-friendly disposal of domestic waste; } \\
\text { Green household consumption }\end{array}$ \\
\hline \multirow{2}{*}{$\begin{array}{l}\text { Educational } \\
\text { concepts }\end{array}$} & Education reform & Recognize the significance of ESD \\
\hline & Value education & Cultivate students as the agents for SD \\
\hline
\end{tabular}

Professional values in ESD involve environmental, economic, and social dimensions of sustainable development in terms of sustainability awareness, attitudes, and behaviors (Biasutti et al., 2017). These three dimensions are viewed as interrelated and intertwined: The environmental value concerns with the vulnerability of the resources and the physical environment; the social value is based on a system of democracy, which enables people to become responsible global citizens and actively participate in pushing society in a sustainable direction; the economic value exerts fundamental impact on the other two dimensions in terms of potential economic growth and economic limits. Language teachers' professional values should be considered essential in developing students' environmental and ethical awareness in humanity that is consistent with sustainable development (Biasutti et al., 2017). Their favourable dispositions towards sustainable human development as well as their sustainable practice in daily life help diffuse values and attitudes into sustainability education. 
Furthermore, higher education institutions should lead to the development of interdisciplinary education to address sustainability issues and advocate sustainable development (UNESCO, 2014). Sustainability education is far from knowledge input and general ability training but has become a cultural awareness that shapes people's worldview, attitudes and lifestyle choices. It guides people to establish sustainable values and form sustainable behaviors.

Accordingly, language teachers in higher education, therefore take on an unparalleled role in the promotion of sustainability education through their educational activities and interactions with external agencies and communities (Minguet et al., 2011). Naturally, being ESD role models for students, language teachers become a strong spiritual driving force and exert a direct and profound impact on the establishment of students' sustainable values. One of the most indispensable elements in sustainable values is the concept of 'teacher spirit' (Zhu, 2017). In this regard, the International Teacher Education Forum has also formed a consensus that in order to be an outstanding ESD practitioner, teachers must also possess the basic qualities and characteristics of dedication, responsibility, integrity and love of education.

Following the guidelines of the international communities of sustainable development, China also regards the construction of ecological civilization as a national development strategy and dedicates to incorporate sustainability into its formal education systems, in all relevant subjects, and in non-formal and informal education. It is believed that ESD is a kind of positive education based on a deep sense of social crisis and responsibility towards the future of human being. It discovers practical problems of unsustainable development in the social, economic, environmental and cultural fields, and guide students to think critically and use innovative ability to propose solutions to these problems.

Sustainable development education has formed its own unique educational concept in practice, that is, the activities of sustainable development education are action-oriented and student-centered, and focus on the development of students' critical thinking ability and innovation and problem-solving ability. Understanding and implementing these concepts in practice is an essential factor for teachers' sustainable development of education capabilities.

2. Professional knowledge

Mastering a series of professional knowledge of sustainable development education is a prerequisite for teachers to carry out sustainable development education and teaching activities and ensure teaching quality. Extensively selecting thirty aspects of global issues that must be addressed in education for sustainability, Zhang (2019) has classified them into two major categories, that is, general knowledge and scientific knowledge of sustainable development.

TABLE II.

TEACHERS’ PROFESSIONAL KNOWLEDGE OF ESD

\begin{tabular}{|c|c|c|c|}
\hline Dimension & Category & Sub-category & Indicators \\
\hline \multirow[t]{2}{*}{$\begin{array}{l}\text { Professional } \\
\text { knowledge }\end{array}$} & $\begin{array}{l}\text { General } \\
\text { Knowledge } \\
\text { of ESD }\end{array}$ & $\begin{array}{l}\text { Understanding of ESD } \\
\text { process and purpose }\end{array}$ & $\begin{array}{l}\text { Be able to understand: } \\
\text { Origin and process of SD; } \\
\text { Origin, goal and process of ESD; } \\
\text { Origin, goal, process and organizations of ESD in your country. }\end{array}$ \\
\hline & $\begin{array}{l}\text { Scientific } \\
\text { Knowledge } \\
\text { of ESD }\end{array}$ & $\begin{array}{l}\text { Scientific } \\
\text { knowledge of } \\
\text { SD }\end{array}$ & $\begin{array}{l}\text { Be able to understand: } \\
\text { Basic knowledge of environment (ecology, biodiversity, climate change, } \\
\text { environmental pollution and prevention, natural disaster prevention); } \\
\text { Basic knowledge of economic field (circular economy, green consumption, } \\
\text { sustainable urbanization, rural development and poverty eradication); } \\
\text { Basic knowledge of social areas (life and security, civil rights and responsibilities, } \\
\text { peace and non-violence); } \\
\text { Basic knowledge of cultural areas (cultural diversity, world heritage, traditional } \\
\text { culture); } \\
\text { Basic knowledge of sustainable lifestyle, green consumption; low-carbon life. }\end{array}$ \\
\hline
\end{tabular}

Professional knowledge of ESD will equip language teachers with knowledge of sustainable development and with concerns for environmental, social, economic and cultural sustainability. It will also enable language teachers to grow more competent and confident and increase their opportunities for acting for a productive and healthy life in harmony with nature (UN, 2002).

On the one hand, it is evident that ESD has undertaken quite a journey after the concept of sustainable development had been recognized and promoted universally. What's more, ESD is acknowledged as a lifelong process of learning from early childhood to higher education even to the whole life of people. With heightened general knowledge of sustainable development, such as the origin of sustainability, the history of ESD, the ultimate goals of ESD, the policies and regulations of international and national institutions of sustainable development, educators can be more effective in spreading sustainable ideas implemented in discipline teaching.

On the other hand, scientific knowledge of ESD covers a broad and comprehensive range of concepts, encompassing interrelated environmental, economic, social and cultural issues. Among which, key themes of sustainable development include poverty alleviation, peace, ethics, citizenship, democracy and governance, justice, security, human rights, health, responsibility in local and global contexts, gender equity, cultural diversity, production and consumption pattern, rural and urban development, environmental protection, corporate responsibility, natural resource management and biological and landscape diversity, and so on (UN, 2002).

The development of a sustainable society should be seen as a continuously evolving process during which issues and 
dilemmas will be explored, and appropriate answers and solutions will be proposed as people's experience increases. Therefore, sustainability education should be elaborated and complemented in an integrative and holistic approach.

3. Professional skills

Constructivist learning theories and learner-centered methodologies should be considered in order to produce effective improvement in the quality of knowledge and values of sustainability (McNaughton, 2012; Scoullos et al., 2017; Biasutti \& Frate, 2017). More importantly, innovative teaching methods with ESD characteristics should be adopted. For instance, sustainability education is supposed to be interdisciplinary and holistic. It implements learner-centered teaching approach to promote students' critical thinking and problem solving ability both within the classroom and in multilateral collaborations with schools, local communities, private sectors, non-government organizations, and so forth.

Regarding professional skills, the following characteristics of ESD teaching methods outlined by Scoullos et al. (2017) are considered: task-based teaching, student-centered teaching methods, higher-order thinking skills, future-oriented thinking, innovative thinking, critical thinking, interdisciplinarity, linking theory with practice and linking local and global issues. Language teachers' ESD professional skills are summarized into two categories of teaching skills and instructive skills with six subcategories (Table 3).

TABLE III.

TEACHERS' PROFESSIONAL SKILLS OF ESD

\begin{tabular}{|c|c|c|c|}
\hline Dimension & Category & Sub-category & Indicators \\
\hline \multirow[t]{6}{*}{ Professional skills } & $\begin{array}{ll}\text { ESD teaching } \\
\text { skills }\end{array}$ & Teaching mode & $\begin{array}{l}\text { Be able to implement: } \\
\text { Interdisciplinary teaching of ESD; } \\
\text { Student-centered teaching approach; } \\
\text { Value education. }\end{array}$ \\
\hline & & $\begin{array}{l}\text { Learning } \\
\text { strategy }\end{array}$ & $\begin{array}{l}\text { Be able to: } \\
\text { Raise students' motivation and initiatives; } \\
\text { Master learning strategies of inquiry-learning, experiential learning, critical learning, } \\
\text { social learning, etc.; }\end{array}$ \\
\hline & & Teaching design & $\begin{array}{l}\text { Be able to: } \\
\text { Explore ESD value within specific discipline; } \\
\text { Establish teaching goals of ESD in line with students' level; } \\
\text { Integrate SD theme into syllabus; } \\
\text { Design student-centered and real-life learning activities. }\end{array}$ \\
\hline & & $\begin{array}{l}\text { Teaching } \\
\text { principles }\end{array}$ & $\begin{array}{l}\text { Be able to: } \\
\text { Launch interdisciplinary feature lectures, seminars, etc.; } \\
\text { Organize team-work project in SD learning; } \\
\text { Cultivate critical thinking and innovative thinking. }\end{array}$ \\
\hline & & Assessment & $\begin{array}{l}\text { Be able to: } \\
\text { Grade students' learning process and results objectively; } \\
\text { Formative evaluation of students' achievement (raising questions, social practice, task } \\
\text { fulfillment, peer-review, etc.); } \\
\text { In-time feedback. }\end{array}$ \\
\hline & $\begin{array}{l}\text { ESD instructive } \\
\text { skills }\end{array}$ & $\begin{array}{l}\text { Instructive } \\
\text { skills in SD }\end{array}$ & $\begin{array}{l}\text { Be able to: } \\
\text { Collect data and analyze SD incidents globally; } \\
\text { Observe and analyze SD issues in multiple perspectives; } \\
\text { Interact with external agencies and communities. }\end{array}$ \\
\hline
\end{tabular}

The first and foremost category of professional skills lies in the teaching skills of ESD language teachers. It covers altogether five aspects: teaching mode, learning strategy, teaching design, teaching principles and assessment.

The teaching mode refers to the approaches language teachers adopt to implement sustainability education, such as student-centered teaching, interdisciplinary teaching, and value education. It aims to strengthen students' motivations and initiatives in the mastery of several learning strategies. The teaching design ability refers to the use of different teaching principles and strategies as well as students' participation in designing a variety of situational issues or problems to which students are guided and facilitated by the language teacher to work out the solutions. In this process, students' critical thinking and communicative skills are promoted in a positive and effective learning environment.

In teaching practice, language teachers should bear a strong awareness of sustainable development and enhance their competence to integrate the idea of sustainable development into the curriculum. Their professional competences in ESD are demonstrated in two ways. On the one hand, language teachers play a role model in maintaining a sustainable lifestyle and a consistent interest in sustainable development in both local and international contexts. On the other hand, teachers should be able to evaluate the teaching and learning outcomes in their ESD practices. By means of objective and scientific formative evaluation system, language teachers' professional competences and students' learning abilities could be promoted to a great extent.

The second major category of professional skills is ESD language teachers' instructive skills. A reoriented focus is required from solely providing knowledge to enhancing students' hands-on capabilities of handling real-life situations and identifying possible solutions. ESD language teachers themselves should also possess such key skills as the abilities to collect and analyze sustainable development events from a multi-dimensional perspective as well as propose innovative solutions. It would exert an impact on the structure of teaching and learning programs and would also change 
language teachers' role of merely a knowledge transmitter.

\section{CONCLUSION}

Under the current national strategic goal of building ecological civilization, the education for sustainable development at schools of all levels is the essential foundation of the national sustainable construction. ESD paves a path for students to master the skills, knowledge, attitudes and values which enable them to take responsible actions and informed decisions and eventually make a contribution to sustainable development in aspects of environmental, economic, and societal improvement for present and future generations. Hence ESD has been given a significant role in raising students' sustainable awareness and reinforcing their skills involved in sustainable development. Therefore, there is an urgent need to build the capacity of educators on issues of teaching and learning methodologies related to sustainability education. Language teachers, equipped with professional knowledge and skills, are more capable of advocating ESD teaching and activities at high standards. More importantly, studies on the construction of language teachers' professional competence in ESD will also provide references for teacher education and evaluation both within and beyond the institutions.

ESD has been integrated into teacher training in institutions of all kinds. Educators are expected to enhance their competences to teach sustainability issues, conduct praxis-oriented interdisciplinary research, and inform policies on ESD and sustainable development (UNESCO, 2014). They are taken as one of the most important levers in facilitating sustainability learning and fostering educational reform.

Educational institutions and policy makers should acknowledge and reward language teachers who advocate for sustainability by means of focusing on multidisciplinary education, critical thinking and community engagement. It is indicated that colleges and universities should initiate a holistic strategy to incorporate sustainability education into their core values (Pompeii et al., 2019). Language teachers' professional competences would be tremendously strengthened if their teaching excellence, academic research and ESD practice could be recognized and awarded, which is essential to the complex process of sustainability education in higher education.

\section{ACKNOWLEDGEMENTS}

We wish to thank the Shanxi Scholarship Council of China and Yuncheng University for their support and funding of the "Research Project for Returned Overseas Scholars" (2016-107) and "Research Project of Teaching Reform" (JGX $07 \&$ JG201804) respectively.

\section{REFERENCES}

[1] Barth, M., \& Rieckmann, M. (2012). Academic staff development as a catalyst for curriculum change towards education for sustainable development: An output perspective. Journal of Cleaner Production, 26, 28-36.

[2] Besong, F., \& Holldan, C. (2015). The dispositions, abilities and behaviors framework for profiling learners' sustainability competencies in higher education. Journal of Teacher Education for Sustainability, 17(1), 5-22.

[3] Biasutti, M., \& Frate, S. (2017). A validity and reliability study of the attitudes toward sustainable development scale. Environmental Education Research, 23(1-2), 214-230.

[4] Biasutti, M., Makrakis, V., Concina, E., \& Frate, S. (2017). Educating academic staff to reorient curricula in ESD. International Journal of Sustainability in Higher Education, 19(1), 179-196.

[5] Filho, W. L. (2015). Education for sustainable development in higher education: Reviewing needs. In Leal Filho, W.L. (Ed.), Transformative approaches to sustainable development at universities. Switzerland: Springer.

[6] Gao, L. X., \& Zhang, L. J. (2020). Teacher learning in difficult times: Examining foreign language teachers' cognitions about online teaching to tide over Covid-19. Frontiers in Psychology, 11(6), 1-14.

[7] Longhurst, J. (2014). Education for sustainable development: Guidance for UK higher education providers. Gloucester, UK: The Quality Assurance Agency for Higher Education.

[8] Mcnaughton, M. J. (2012). Implementing education for sustainable development in schools: Learning from teachers' reflections Environmental Education Research, 18(6), 765-782.

[9] Michalos, A. C., Creech, H., Mcdonald, C., \& Kahlke, P. M. H. (2011). Knowledge, attitudes and behaviours. Concerning education for sustainable development: Two exploratory studies. Social Indicators Research, 100(3), 391-413.

[10] Minguet, A.P., Martinez-Agut, M.P., Palacios, B., Pinero, A., \& Ull, M.A. (2011). Introducing sustainability into university curricula: An indicator and baseline survey of the views of university teachers at the University of Valencia. Environmental Education Research, 17(2), 145-166.

[11] Natkin, L. W., \& Kolbe, T. (2016). Enhancing sustainability curricula through faculty learning communities. International Journal of Sustainability in Higher Education, 17(4), 540-558.

[12] Olsson, D., Gericke, N., \& Rundgren, S. N. C. (2016). The effect of implementation of education for sustainable development in Swedish compulsory schools: Assessing pupils' sustainability consciousness. Environmental Education Research, 22(2), 176-202.

[13] Pompeii, B., Chiu, Y. W., Neill, D., Braun, D., Fiegel, G., Oulton, R., \& Singh, K. (2019). Identifying and overcoming barriers to integrating sustainability across the curriculum at a teaching-oriented university. Sustainability, 11(9), 2652.

[14] Scoullos, M., Vicky, M., Paula, L., \& Sinikka, S. (2017). Learning for and about sustainability in higher education: A regional perspective based on experiences from the Baltic and the Mediterranean. International Journal of Sustainability in Higher Education, 18(6), 877-893. 
[15] Tilbury, D. (2011). Education for sustainable development: An expert review of processes and learning. Paris: UNESCO.

[16] UN, United Nations. (2002). Report of the World Summit on Sustainable Development, Johannesburg. Available at: http://www.johannesburgsummit.org/html/documents/ummit-docs/13102_wssd_report_reissued.pdf. Accessed 20 October 2020.

[17] United Nations Educational, Scientific, and Cultural Organization (UNESCO). (2014). UNESCO roadmap for implementing the Global Action Programme on Education for Sustainable Development. France: UNESCO.

[18] Wals, A. E. J., Meng Yuan, J., \& Mukute, M. (2014). Social learning-oriented ESD: Meanings, challenges, practices and prospects for the post-DESD era. Paris: UNESCO.

[19] Xi, J. P. (2017, January 20). Jointly build a community with a Shared future for mankind: A speech at Geneva headquarter of UN. China Daily. p. 2.

[20] Zhang, X. Y. (2019). Construction of teachers' educational ability for sustainable development. Journal of Beijing Institute of Education, 33(3), 41-47.

[21] Zhu, X. D. (2017). Teachers' role in new era. People Education, 17(3), 14-16.

Yan Liu is currently a lecturer at Yuncheng University, China. She received her Master degree of Applied Linguistics in Southwest Jiaotong University (China) in 2008. Her research interests include English language learning and teaching, social linguistics, and teacher education.

Wenjin Qi is currently a PhD candidate at Woosong University, South Korea. She received her Master degree of Social Linguistics in Nanyang Technological University (Singapore) in 2016. Her research interests include English language learning and teaching, interdisciplinary study of social semiotics in tourism discourse, and teacher education. 